Majied Robinson

Marriage in the Tribe of Muhammed 



\section{Majied Robinson}

\section{Marriage \\ in the Tribe \\ of Muhammed}

A Statistical Study

of Early Arabic Genealogical Literature

\section{DE GRUYTER}


ISBN 978-3-11-062416-8

e-ISBN (PDF) 978-3-11-062607-0

e-ISBN (EPUB) 978-3-11-062423-6

Library of Congress Control Number: 2019946051

Bibliographic information published by the Deutsche Nationalbibliothek

The Deutsche Nationalbibliothek lists this publication in the Deutsche National-

bibliografie; detailed bibliographic data are available on the Internet at http://dnb.dnb.de.

(c) 2020 Walter de Gruyter GmbH, Berlin/Boston

Cover image: $\odot$ by Andrew Meehan, used with permission

Printing and binding: CPI books $\mathrm{GmbH}$, Leck

www.degruyter.com 